Essay

\title{
Unpacking the Concept of Competence for Effective Integration in the Curriculum Design
}

\author{
María Napal Fraile ${ }^{1, *}$, Alicia Peñalva Vélez ${ }^{2}$ and \\ Ana María Mendióroz Lacambra ${ }^{3}$ \\ 1 Science Department. Universidad Pública de Navarra - Spain; maria.napal@unavarra.es \\ 2 Human and Social Sciences Department. Universidad Pública de Navarra - Spain; \\ alicia.penalva@unavarra.es \\ ${ }^{3}$ Human and Social Sciences Department. Universidad Pública de Navarra - Spain; \\ anamaria.mendioroz@unavarra.es \\ * Correspondence: maria.napal@unavarra.es; Tel.: +34-948169493
}

\begin{abstract}
Traditional educational approaches have been more concerned with the transmission of knowledge and skills than with the introduction of values and attitudes, or, in other words, with the holistic upbringing of learners "competent for life". However, already by the end of the XX century it became clear that education should have a more relevant role in fostering achievement of individuals' aims and also social and economic welfare. All this created the breeding ground for the emergence of the concept of "competence". However, for the time being, there is not a unique, distinct definition of "competence", which makes it scarcely operative and hinders application in educational planning. In this context, competence is being used non-uniformly, and often as a mere declaration of intent, and this is creating ambiguity regarding the design of competence based teaching. Taking into account all the above, we are proposing the development of a practical evaluation scheme, based on specific indicators (tags), which allows analysing the contribution of specific educational resources to the development of the scientific competence. We define our framework for the definition of scientific competence, define its relevant dimensions and set the criteria and intended steps for the development of the system of indicators.
\end{abstract}

Keywords: Competence; competency; competence-based education; educational planning; scientific competence; scientific literacy; skills.

\section{Introduction}

The onset of the XXI century, coincident with the turn of the millennium, meant a turning point in several areas: education, environment, economic development... Looking back to the tumultuous second half of the XX century, which brought progress but also disillusionment and inequality, Jacques Delors, on behalf of the European Commission, claimed for an education able to "foster a deeper and more harmonious form of human development and thereby to reduce poverty, exclusion, ignorance, repression and war" [1]. Education, thus, appears as central to personal and community development; its mission is to enable each of us, without exception, to develop all our talents to the full and to realize our creative potential, including responsibility for our own lives and achievement of our personal aims, but also involvement in one's social roles at work and in the community [1]. 
On the other hand, the Organization for the Economic Cooperation and Development (OCDE) pointed out the need that education addresses the complexity of the demands generated by an increasingly interdependent, changing and conflictual world [2]. In other words, education needed to equip individuals with the resources to lead an overall successful and responsible life, and, in the last term, contemporary society to face present and future challenges. Indeed, in the last decades there is a sector of society interested in education producing measurable outcomes, resulting in the development of certain abilities to enter the labour market efficiently [3].

However, traditional educational approaches have been more concerned with the transmission of knowledge and skills than with the introduction of values and attitudes, or, in other words, with the holistic upbringing of learners "competent for life". This decontextualized learning could be one of the reasons behind the growing and generalized disaffection with education, and the perceived lack of effect in real life. All in all, teaching practice had revealed that teaching knowledge contents and abilities, without encouraging the development of the mental capabilities that are involved in their acquisition, resulted in very weak learning outcomes [4].

All this created the breeding ground for the emergence of the concept of "competence", which has permeated the educational design since then. The introduction of the term competence into the conceptual universe of education meant a significant step forward in the ongoing change of educational paradigm: the traditionally dominant role of conceptual knowledge began to be questioned, as more recognition was given to the development of abilities, skills, values and attitudes. Besides, conceptual contents started to be seen as interconnected pieces authentic problems in real life are complex, not limited to single areas of the curriculum -, and it became clear that competence had to be pursued by all curriculum areas; formal education contexts started to give more space to nonformal and informal ones, and learning began to be understood as something ubiquitous and life-long.

\section{Definition of competence}

However, for the time being, there is not a unique, distinct definition of "competence". Indeed, although it is possible to find common ground, the concept can be approached from multiple perspectives [3], so that one of the obstacles to pursuing competence-based teaching is that the term could be too vague and indeterminate for being operatively useful. Thus, the first step towards operationalization should be agreeing upon a minimum set of criteria that are core to the concept.

In general terms, competence could be considered as the minimum cultural endowment that citizens need to thrive in life. However, this conception may have different meanings. Back-to the two main currents that have been presented in the 
introduction, those who place themselves conceptually closer to the original use of the term in professional scenarios, competence is a measure of human capital, a predictor of the individual productivity in the labour market. For other traditions, competence is conceived as empowerment; that is to say, the process of transforming knowledge into power or social action [5]. In this respect, UNESCO established the four pillars on which education for the XXI century should be based: learning to know, learning to do, learning to be and learning to live together [1].

From both perspectives, and considering the various approaches that have been mentioned, it is possible to find some commonalities on which a functional definition could be based: Developing competence requires, first of all, knowledge (Know, or know- what). That is to say, an underlying cognitive structure, based on theoretical, procedural, methodological and attitudinal knowledge. Complex thinking skills (metacognitive and strategic ones) which arise from this knowledge enable the competent learner to act in a conscious, coordinate, integrated, effective, fast and creative [5]. That cognitive structure is developed through training and experience (Know- how), in what constitutes a progressive, endless process of constant updating, which can only take place through action. As a result, competences are only demonstrable in action [6]. In addition to that, the development of competence is linked to personality, a series of characteristics that are intrinsic to the person, including motivation, self-concept, abilities, etc. The desire to do and the know how to be derive from these personality factors. The overall process of competence development enables the learner to play a role efficiently; i.e., to solve problematic questions in complex situations and within given contexts, with autonomy and flexibility [7] (Figure 1).

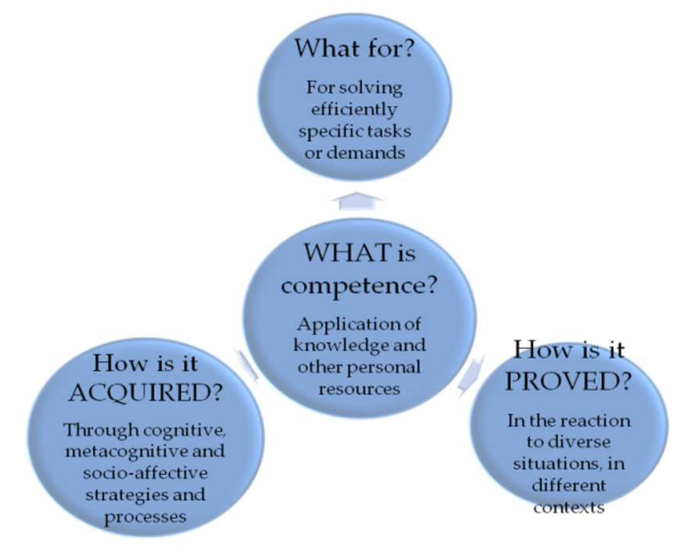

Figure 1. A functional definition of competence.

In other words, competence could be defined as the way by which people mobilize diverse personal resources of their mental structure in an orderly and integrating manner in order to respond satisfactorily, successfully and effectively 
to specific complex tasks, defined in specific contexts or situations, and under given conditions [8-10]. In this definition, personal resources may encompass concepts, skills, attitudes, expertise, abilities (intellectual, physical and social ones), aptitudes, values, emotions, affections, motivation, etc. [11].

Competence-based approaches seek to dissociate from the academic logic of disciplines and to promote an educative model in which to integrate the academic, professional and vital perspectives, from a multi and transdisciplinary perspective [12].

In summary, the competence involves structured knowledge about the activity and the most effective strategy to tackle it; some practical experience; and also the ability to reflect on and assess one's work, and make the corrections that are needed. As McClelland [13] defined them, "a sum of knowledge, skills, and aptitudes, which contributes to the capacity of a person to effectively perform the duties and responsibilities of the occupied job; in other words, to be competent".

For all purposes, competences can only be understood, assessed and developed from a defined and clear theoretical framework [5]. In this way, three main approaches [14] could be considered to the concept of competence, understood as knowledge put into action [15]:

- Behavioural approach: Competence as a set of abilities that ensure productivity in the labour market. In this approach, with roots in the United States, competences are understood as a demonstration of behaviour; i.e., the traits that allow him/her to perform professionally.

- Functional or generic approach: Competence as the knowledge, skills, and aptitudes that make people able to solve a task under set conditions. It seeks to identify abilities and features that explain variation in performance in specific contexts.

- Constructivist-holistic approach: Competence as the knowledge about how to mobilize the elements of the competence in order to solve a task satisfactorily; to want, to have personal motivation; and to be able to do, thanks to a context and conditions that make the solution of the task possible.

These multiple meanings emerge as a consequence of the existence of several theoretical frameworks, which arise from different conceptions of society and person, and consequently set different aims for education. Eventually, the concept attached to the term competence will condition the approach from which teaching and learning will be developed.

\section{Taxonomy of competences}

Designing teaching based on competences also requires defining the type of competences we are working with. Sarramona [16] identifies four main categories, which can be further subdivided: 
1. Basic competences: related to basic education (compulsory school period); they refer to the set of minimum requirements that a contemporary citizen should acquire at the end of compulsory schooling. They include curricular competences (relative to different domains of knowledge, or subjects) and transversal competences (broad, integrative skills required for the holistic development of learners; [17])

2. Technical- professional competences: linked to vocational training (postcompulsory secondary education), including qualification- specific competences (analogous to the curricular competences) and the transversal ones (which are subject to training and development all the way through schooling).

3. Key competences: owned and developed by the individual throughout its entire life. Key competences are responsible for individual success throughout the entire life, and to the good global functioning of the society derived from the action of particular citizens [11]. The term was introduced by the OECD [2,18] but was widely adopted by developed countries to inspire renewed educational policies. These competences aim for a broad spectrum of applicability and, therefore, go beyond strictly curricular ones and are more closely related to the transversal ones [19].

4. Professional competences: linked to Higher Education, they are associated with effectively performing certain professional tasks. They involve the capacity to solve complex professional questions, by mobilizing scientific knowledge and technical abilities, and respecting ethical considerations typical of that particular profession. Professional competences can be distinguished in specific and generic ones: generic competences, such as those described in the Tuning Project [20], are common to every graduate from Higher Education, whereas specific competences refer to the specific career paths.

These four categories are, by no means, self-contained groups (Figure 2). Basic competences are the basis of all the other categories, as they provide the foundations for learning along life. Basic competences must be aimed to equip the learner (citizen to be) with the minimum indispensable tools for comprehending and acting in our current world. Key competences, in turn, are tightly linked to basic competences but go well beyond them, as they have a much broader applicability. As it has been already said, key competences exceed the curricular competences directly linked to a curricular area or subject and must be developed throughout life. These transversal competences are of the utmost importance and should be treated in all subjects of the curriculum as guarantors of an integral formation of the person $[19,21]$.

Knowledge and practical abilities (Know-what, Know-how), primarily tackled by basic competences, are easier to detect, develop and evaluate, but cannot (alone) ensure proficiency is task solving. They are the hidden aspects that lie below the surface - like attitude, traits, thinking styles, self-concept, social skills, behaviour, 
etc. - what directly influence the use of knowledge and skills to complete a job effectively (Iceberg model, [22].

For a better understanding of the nature of "Key competences", it may be useful to examine the three competences identified by the project DeSeCo [2] as key to success in life and the good functioning in society (Table 1).

Table 1. Key competences according to DeSeCo [2]

\section{Competences}

To act

autonomously

\begin{tabular}{|c|c|}
\hline $\begin{array}{l}\text { To act } \\
\text { autonomously }\end{array}$ & $\begin{array}{l}\text { ability to defend and take care of } \\
\text { one's rights, interests, } \\
\text { responsibilities, limits and needs } \\
\text { ability to form and implement } \\
\text { life plans and personal projects } \\
\text { ability to act within a significant/ } \\
\text { wide context }\end{array}$ \\
\hline $\begin{array}{l}\text { To use resources } \\
\text { interactively }\end{array}$ & $\begin{array}{l}\text { Ability to use language, symbols } \\
\text { and texts interactively } \\
\text { Ability to use knowledge and } \\
\text { information literacy interactively } \\
\text { Ability to use the (new) } \\
\text { interactive technologies } \\
\text { interactively }\end{array}$ \\
\hline $\begin{array}{l}\text { To act in } \\
\text { heterogeneous } \\
\text { social groups }\end{array}$ & $\begin{array}{l}\text { Ability to interact successfully } \\
\text { with others } \\
\text { Ability to co-operate } \\
\text { Ability to manage and to resolve } \\
\text { conflicts }\end{array}$ \\
\hline
\end{tabular}

\section{Related abilities}




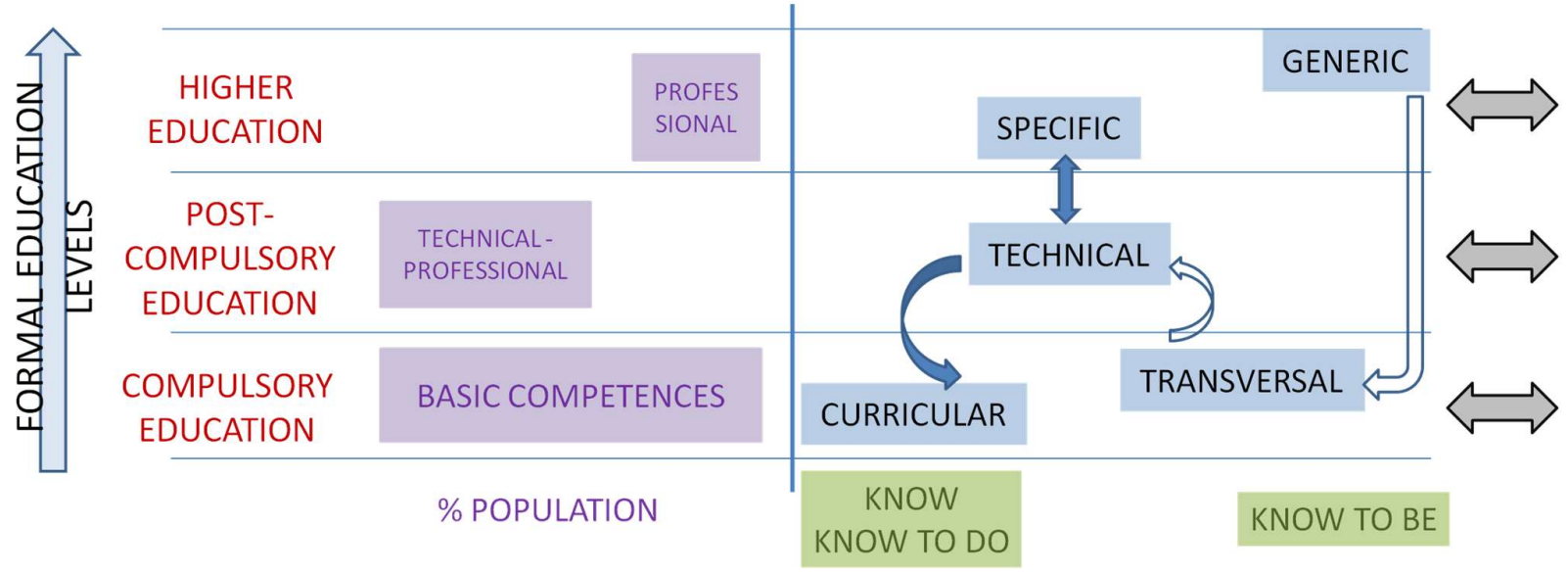

Figure 2. Taxonomy of competences

As said before, these different frameworks differ in their conceptions of both individual and society, and this, in turn, determines how they conceive education and its aims and, in the last term, the meaning "competence". Table 2 shows a comparison of the three most popular perspectives for the definition of key competences which in turn have inspired the definition of basic competences in national curricula and international evaluation schemes (Figure 3).

Table 2. Comparison of major frameworks for the definition of key competences.

\begin{tabular}{|c|c|c|c|}
\hline Source & Definition & Elements & Goal \\
\hline Council of Europe & $\begin{array}{l}\text { The ability of an } \\
\text { individual to } \\
\text { perceive and } \\
\text { respond to social } \\
\text { and individual } \\
\text { needs, }\end{array}$ & $\begin{array}{c}\text { knowledge (key } \\
\text { ideas or support } \\
\text { knowledge) } \\
\text { skills (general } \\
\text { skills; fundamental } \\
\text { ways of } \\
\text { learning) } \\
\text { attitudes } \\
\text { values }\end{array}$ & $\begin{array}{l}\text { Ensure individual } \\
\text { fulfilment and } \\
\text { good functioning } \\
\text { of the society }\end{array}$ \\
\hline $\begin{array}{c}\text { International } \\
\text { Board of Standards } \\
\text { for Training, } \\
\text { Performance and } \\
\text { Instruction } \\
\text { (IBSTPI) }\end{array}$ & $\begin{array}{l}\text { The ability to } \\
\text { perform an } \\
\text { activity, to carry } \\
\text { out work or task in } \\
\text { a qualified way }\end{array}$ & $\begin{array}{l}\text { knowledge, skills } \\
\text { and } \\
\text { attitudes that } \\
\text { allow an } \\
\text { individual fulfil } \\
\text { work or functions } \\
\text { following definite }\end{array}$ & Act professionally \\
\hline
\end{tabular}




\begin{tabular}{|c|c|c|c|}
\hline $\begin{array}{c}\text { OECD } \\
\text { DeSeCo project [2] }\end{array}$ & $\begin{array}{c}\text { ability to } \\
\text { successfully meet } \\
\text { individual and } \\
\text { social demands, to } \\
\text { act and to carry } \\
\text { out the assigned } \\
\text { tasks }\end{array}$ & $\begin{array}{l}\text { knowledge, skills, } \\
\text { values and } \\
\text { attitudes according } \\
\text { to school subjects } \\
\text { and life areas }\end{array}$ & $\begin{array}{c}\text { Individual, social } \\
\text { and economic } \\
\text { wealth to improve } \\
\text { productivity, } \\
\text { competitiveness } \\
\text { and } \\
\text { innovativeness; to } \\
\text { reduce } \\
\text { unemployment. } \\
\text { Participation in } \\
\text { society, reducing } \\
\text { inequality and } \\
\text { marginalization. }\end{array}$ \\
\hline
\end{tabular}

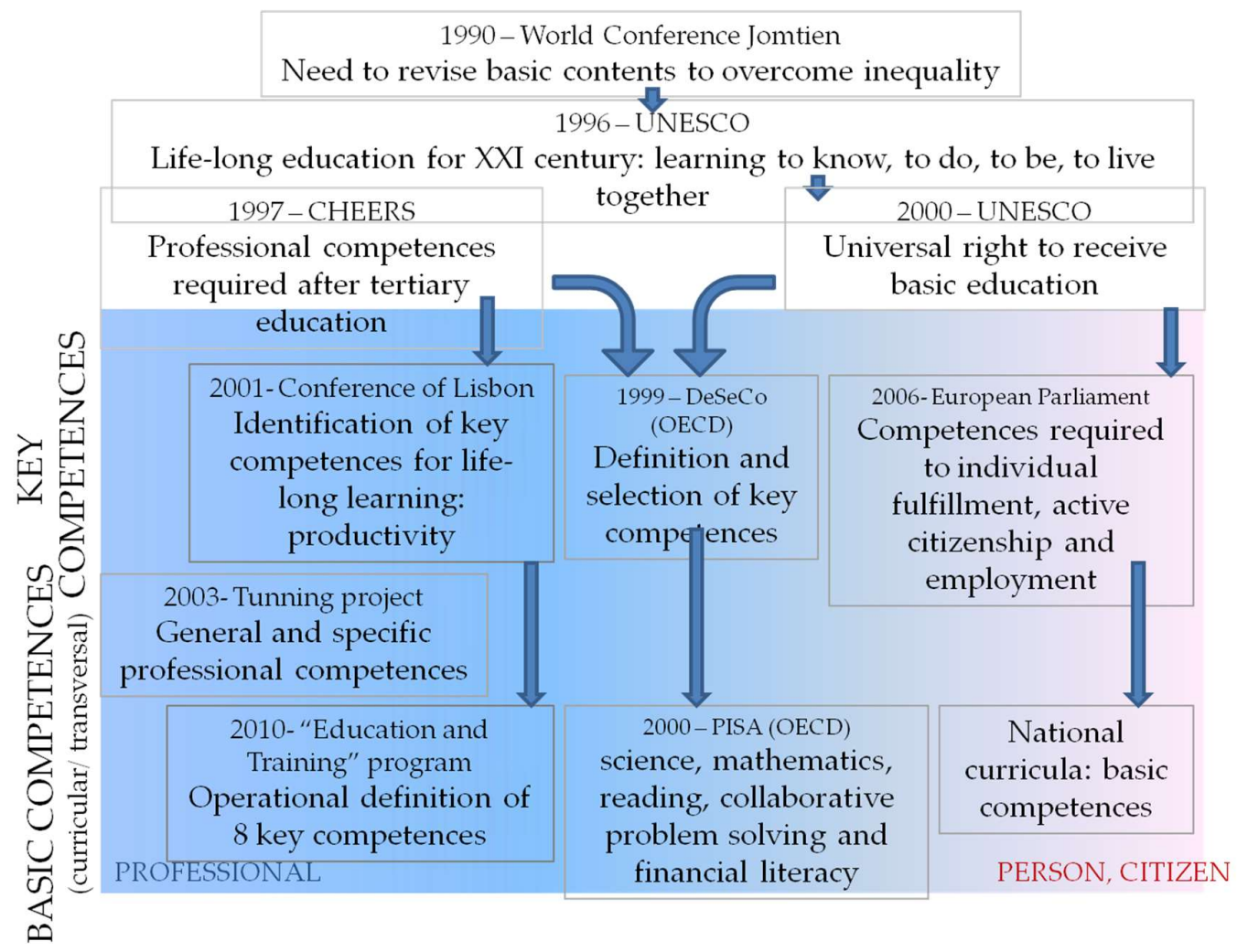

Figure 3. Historical evolution of the different frameworks for the definition of competence mentioned in the text 


\section{Competence-based teaching}

Even if we were able to converge to a single definition, the transformation of the education system requires much more than incorporating the word "competence" to our everyday lexicon.

For the time being, there is not a single theoretical model of competence, complex enough not only for defining clearly the concepts of competence, capability, ability, contents, etc., but also for establishing connections between them [8]. So, elucidating the complex (and not linear) interconnection that exists between all these elements is still a challenge to meet.

Defining learning in terms of competence makes evident the necessity of acquiring knowledge in a way that ensures it can be adequately mobilized for solving tasks [23]. In this way, being able to define learning in terms of competence has the advantage of jointly considering the contents and the activities/ contexts, because the competence is a way of mobilizing all the available resources (knowledge, attitudes, and skills) in certain conditions and for a given purpose.

Competences are including concepts, which should encompass and be integrated into the various areas of learning, in such a way that all the areas of the curriculum contribute, from their respective field, in the development of one or more competences. In doing so, the competences must be closely linked to the curricular objectives, so that the achievement of the objectives implicitly involves the development of the competences. The selection of contents and methodologies should also serve the development of the competences, while assessing the degree of achievement of the objectives, implicitly report the degree of development of the competences that has been reached [9].

On their part, teachers are responsible for substantiating educational policies in the classroom. Every act of educational planning (also competence-based planning), responds to different levels of curricular application. What to teach, how to teach and when to teach it are defined in three nested levels (Figure 4): public administrations (educational policies), schools (Educational Centre Plans, according to particular agendas), and classroom (planning suited to the particular needs and features of the group) [24]

However, these two levels - educational policies aimed to raise competences; curriculum design for the classroom - are difficult to reconcile in the practice (Figure 4). On the one hand, competence is most often used as a (rather bold) declaration of intent, which is only expressed in general terms without a specific definition of the intervening elements (knowledge, skills, values, attitudes). Several authors claim that competence, or literacy, are being used non-uniformly (e.g. scientific literacy; [25]), and this is creating ambiguity regarding calls to promote them. On the other hand, teachers, as designers of learning situations and architects of the teaching-learning process, require tangible or concrete entities on which to base their process of design. 
In particular, planning for the classroom starts with defining the Learning Objectives (Figure 4), also known as Learning Outcomes or Intended Learning Outcomes (ILOs). Learning objectives are brief and clear statements of what students should know or be able to do at the end of the course that they could not do before. Learning objectives may refer to knowledge, skills or attitudes, and must define or describe an action, be measurable (regarding time, space, amount, and frequency), and be differentiated (i.e., specify levels of achievement). According to competence-based schemes, learning objectives should be referred to the competences, in such a way that the sum of Learning Objectives enables creating the profile of each competence.

Again, the main difficulty that practitioners wishing to incorporate the competences may encounter is the lack of definition of the different frameworks. For example, the PISA and Socioscientific Issues (SSI) approaches are seemingly well aligned when considering general aims. Both approaches emphasize preparing students for life and citizenship, complex reasoning and reflective practices, and robust understandings of the nature of science, particularly as it is practiced in society. However, as the focus of comparison moves from the conceptual to more specific, the connections between PISA and the SSI movement become more tenuous [25]. In absence of specific indicators to develop the general framework, basic competences are, in practice, identified with the curricular areas and substantially reduced to the "know" and "know how" dimensions of the competence, or just used within the context of an non-specific discourse about teaching innovation justifying and accompanying the outburst of active methodologies.

EDUCATIONAL POLICIES

CLASSROOM MANAGEMENT
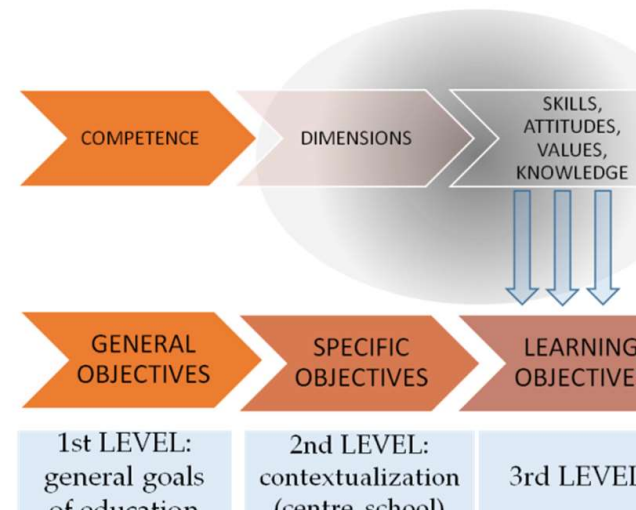
OBJECTIVES

2nd LEVEL: contextualization (centre, school)

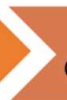
SPECIFIC

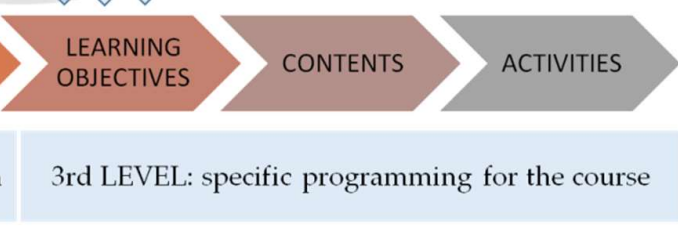

Figure 4. The two levels of educational planning - general policies and specific classroom arrangements - have difficulties in getting together for realizing competence-based teaching.

In other words, effectively incorporating the competences to learning and teaching involves, inexcusably, identifying common ground between curriculum and policies designers (top-down direction) and teachers (bottom-up approaches) (Figure 4). 
11 of 16

\section{Proposal for a scheme for the evaluation of scientific competence}

Taking into account all the above, we are proposing the development of a practical evaluation scheme, based on specific indicators (tags), which enable us and, in the last term, teachers, families and students - to analyse the contribution of specific educational resources to the development of the scientific competence. Although it is primarily intended for evaluation and classification of educational videos, the instrument has characteristics that make it applicable for a variety of resources and formats.

The purpose is to filter and select videos that promote the development of scientific competence, to include them in a platform capable of offering teaching materials that also fulfil a leisure function, and that are safe and interesting for learning, i.e., a platform that is useful in both formal and informal educational contexts. On the one hand, it seeks to offer teachers a practical resource to support the teaching-learning processes, focused on Science (Natural Sciences, with English as the vehicular language) and in the levels of Early Childhood and Primary Education. On the other hand, it is also intended to offer a playful and educational option for use in a family context, as well as for self-consumption by the student himself. This platform is being developed in the context of a collaboration for the knowledge transfer between university and the industry.

In a first step, we will aim to thoroughly characterize scientific literacy, in a way that can be translated to other areas of competence.

Recalling the above debate about the different frameworks for the conceptualization of competences, we need to define first our conceptual "umbrella". After reviewing several classification schemes that had been developed to make sense of various approaches for the conceptualization of scientific literacy, Roberts [26] proposed two overarching visions of science literacy:

Vision I gives meaning to SL by looking inward at the canon of orthodox natural science, that is, the products and processes of science itself. At the extreme, this approach envisions literacy (or, perhaps, thorough knowledgeability) within science ...Vision II derives its meaning from the character of situations with a scientific component, situations that students are likely to encounter as citizens. At the extreme, this vision can be called literacy (again, read thorough knowledgeability) about science-related situations in which considerations other than science have an important place at the table (emphases original; [27] p.230 reported in [25]).

We opt for Vision II, a vision that goes beyond purely technical approaches, focused on the promotion of scientific concepts and processes, which may help students develop robust understandings of scientific findings and formalisms, as well as the skills and processes used within the sciences. On the contrary, we 
defend instead an approach focused on understandings and use of science in situations, involving personal decision-making about contextually embedded issues [25]. In other words, whereas Vision I (sensu [27]) defines what scientifically literate individuals ought to know and be able to do (Professional approaches, Figure 3), Vision II SL looks to situations that present opportunities for individuals to use scientific ideas, processes, and reasoning, and that are thus closer to a holistic view of the competence, understood as knowledge put into action and encompassing the four dimensions (know, know how, know how to be, know to live together).

Accordingly, the indicators, or tags, will be developed as belonging to four main categories, which recall the definition that PISA [18] gives of scientific literacy, concerning an individual's:

- Scientific knowledge and use of that knowledge to identify questions, to acquire new knowledge, to explain scientific phenomena, and to draw evidence-based conclusions about science-related issues.

- Understanding of the characteristics of science as a form as human knowledge and enquiry.

- Awareness of how science and technology shape our material, intellectual and cultural environments.

- Willingness to engage with science-related issues, and with the ideas of science as a reflective citizen.

Each of the dimensions needs then to be developed into a series of concepts, processes (verbs of action) and contextual factors, which allow establishing links with the Learning Objectives, and the way teaching-learning processes are designed, put into practice and evaluated (Table 3).

Table 3. Indicators per dimension of the scientific competence.

\begin{tabular}{|c|c|c|c|}
\hline Dimension & Area & Indicator & Type - examples \\
\hline $\begin{array}{l}\text { CONTENTS } \\
\text { OF } \\
\text { SCIENCE } \\
\text { To know } \\
\text { science/ to } \\
\text { do science }\end{array}$ & $\begin{array}{l}\text { Know } \\
\text { Know } \\
\text { how }\end{array}$ & $\begin{array}{l}\text { Science contents: as defined } \\
\text { by the relevant curriculum or } \\
\text { document of standards } \\
\text { Scientific skills (simple and } \\
\text { complex). }\end{array}$ & $\begin{array}{c}\text { Nouns } \\
\text { pulleys, living beings } \\
\text { Verbs of action } \\
\text { compare, classify, pose a } \\
\text { hypothesis }\end{array}$ \\
\hline $\begin{array}{l}\text { CONTENTS } \\
\text { ABOUT } \\
\text { SCIENCE } \\
\text { To know }\end{array}$ & $\begin{array}{l}\text { Know } \\
\text { Know } \\
\text { how } \\
\text { Know to }\end{array}$ & $\begin{array}{c}\text { Nature of Science, or } \\
\text { epistemology }\end{array}$ & $\begin{array}{c}\text { Adjectives, adjectival } \\
\text { phrases } \\
\text { science is verifiable }\end{array}$ \\
\hline
\end{tabular}




\begin{tabular}{|c|c|c|c|}
\hline $\begin{array}{c}\text { about } \\
\text { science }\end{array}$ & be & & \\
\hline $\begin{array}{c}\text { CONTEXTS } \\
\text { OF } \\
\text { SCIENCE } \\
\text { To be aware } \\
\text { of the } \\
\text { importance } \\
\text { of science }\end{array}$ & $\begin{array}{l}\text { Know to } \\
\text { be, Know } \\
\text { to live } \\
\text { together }\end{array}$ & $\begin{array}{l}\text { Personal attitudes, beliefs, } \\
\text { values. Ethical references } \\
\text { guiding scientific practices. }\end{array}$ & $\begin{array}{c}\text { Nouns, short phrases } \\
\text { collaboration, group } \\
\text { work } \\
\text { sustainable behaviour }\end{array}$ \\
\hline $\begin{array}{l}\text { INTEREST } \\
\text { IN } \\
\text { SCIENCE } \\
\text { To value } \\
\text { science }\end{array}$ & & & \\
\hline
\end{tabular}

Another constraint to be considered is that indicators must be gradable, or susceptible to be ordered to adjust to a progression: competences are developed through a gradual process that starts in elementary school and continues, both within and outside the school, through elementary and secondary school and even beyond. Thus, the architecture of the system must ensure it allows fitting successive levels of complexity.

The major contribution of this proposal is being able to state more accurately the dimensions of the competence, in reference to an explicit higher-order conceptual framework. This, in turn, would provide the concrete entities that ensure educational planning can be made operational, if desired, as based in competences.

The main limitations of this study are related to the lack of theoretical references on which to substantiate a more precise definition of the elements integrating the competence, still in this early stage of the project. This, in turn, determines the way forward in research on the topic.

The next steps, leading to the definition of a complete and functional classification system, will be: first, to revise the relevant curricula, or statements of Educational Standards, to identify relevant contents of science and about science. Second, to launch a proposal of indicators by dimension (as defined in Table 4). This list will go through a 3-step validation process: (1) validation by experts, to check agreement with structuring concepts (big ideas) in science and scientific skills; (2) pilot application to the videos in the platform, to check accuracy (completeness and differentiation); (3) validation with users (teachers) to check comprehensibility and specificity. 
Author Contributions: Conceptualization, M.N, A.P, A.M; writing-original draft preparation, M.N, A.P., A.M.; writing - review and editing, M.N.; project administration, M.N.; funding acquisition, M.N., A.P.

Funding: This research was funded by Departamento de Desrrollo Económico. Gobierno de Navarra, grant number 0011-1365-2018-000124.

Acknowledgements: We acknowledge the contribution of Alejandra Uriz to the formatting and language edition of the text, and her valuable comments which have substantially improved the form and the content of this manuscript.

Conflicts of Interest: The authors declare no conflict of interest. The funders had no role in the design of the study; in the collection, analyses, or interpretation of data; in the writing of the manuscript, or in the decision to publish the results. 
15 of 16

\section{References}

1. Delors J. Learning: the treasure within. Report to UNESCO of the International Commission on Education for the Twenty-first Century [Internet]. Paris, France; 1996.

2. OECD. The definition and selection of key competencies: Executive summary [Internet]. Neuchâtel, Switzerland; 2005.

3. Díaz Barriga A. Competencias en educación. Corrientes de pensamiento e implicaciones para el currículo y el trabajo en el aula. Rev Iberoam Educ Super. 2011;5(2),3-24.

4. Kegan R. Las competencias que funcionan como epistemologías: cómo queremos que los adultos aprendan. In: Rychen DS, Salganik LH, editors. Definir y seleccionar las competencias fundamentales para la vida. Mexico: Fondo de Cultura Económica; 2004.

5. Perrenoud P. La clave de los campos sociales: competenc ias del autor autónomo. In: Rychen DS, Salganik LH, editors. Definir y seleccionar las competencias fundamentales para la vida. Mexico: Fondo de Cultura Económica; 2004. p. 216-61.

6. Pérez Gómez A.I. La naturaleza de las competencias básicas y sus aplicaciones pedagógicas. Cuad Educ Cantab. 2007; 1-34.

7. Zabalza M.A. Competencias docentes del profesorado universitario: Calidad y desarrollo profesional. Madrid: Narcea; 2003.

8. Moya Otero J.;Tiana A. Las competencias básicas: un nuevo perfil educativo para el siglo XXI. In: Ministerio de Educación, Cultura y Deporte ., editor. Guía para la formación en centros sobre las competencias básicas. Madrid, Spain: Secretaría General Técnica del Ministerio de Educación, Cultura y Deporte; 2013.

9. Ley Orgánica 8/2013, de 9 de diciembre, para la mejora de la calidad educativa. Boletín Oficial del Estado BOE 295, del 10 de diciembre de 2013; p. 97858-921.

10. Education U.S.D. of. Defining and Assessing Learning: Exploring Competency-based Initiatives. Washington, DC, USA; 2002.

11. Rychen D.S.;Salganik L.H. Key competencies for a successful life and a well-functioning society. Germany: Hogrefe \& Huber; 2003.

12. Barnett R. The Limits of Competence: Knowledge, Higher Education and Society. Bristol, United States: Open University Press; 1994.

13. McClelland D.A. Testing for competence rather than for "intelligence." Am Psychol. 1973;28,423-447.

14. Mulder M.;Weigel T.;Collins K. The concept of competence concept in the development of vocational education and training in selected EU member states. A critical analysis. J Vocat Educ Train. 2006;59,6585.

15. Mandon N.;Sulzer E. Analysis of work: Describing competences through a dynamic approach to jobs. Train Employ. 1998;

16. Sarramona J. Competencias básicas y currículum. El caso de Cataluña. Teoría la Educ [Internet]. 2014;26(2),205-28.

17. UNESCO. 2013 Asia-Pacific Education Research Institutes Network (ERI-Net) Regional Study on transversal competencies in education policy and practice (Phase I) Regional Synthesis Report. [Internet]. Bangkok, Thailand; 2015

18. OECD. Assessing Scientific, Reading and Mathematical Literacy - A Framework for PISA 2006 [Internet]. France; 2006. DOI: http://www.oecd.org/pisa/39732471.pdf 
19. Sarramona J. Competencias básicas y currículum. El caso de Cataluña. Teoría la Educ. 2014;26(2),205-28.

20. González J.;Wagenaar R. Tuning Educational Structures in Europe [Internet]. Universidad de Deusto: Bilbao, Spain; 2003.

21. Bruxelles Formation. Cadre de Référence. Compétences Transversales [Internet]. 2013.

22. Spencer L.M.J.;Spencer S.M. Competence at work. Models for superior performance. Wiley; 1993. $9780471548096 \mathrm{p}$.

23. Pérez Gómez A.I. La naturaleza de las competencias básicas y sus aplicaciones pedagógicas [Internet]. Vol. 1, Cuadernos de Educación de Cantabria. Santander, Spain: Consejería de Educación de Cantabria; 2007. 1-34 p.

24. Medina Rivilla A.;Domínguez Garrido M.C. Didáctica: formación básica para profesionales de la educación. Madrid: Editorial Universitas; 2009.

25. Sadler T.D.;Zeidler D.L. Scientific literacy, PISA, and socioscientific discourse: Assessment for progressive aims of science education. J Res Sci Teach [Internet]. 2009;46(8),909-21. DOI: http://doi.wiley.com/10.1002/tea.20327

26. Roberts D.A. Scientific literacy/science literacy. In: Abell SK, Lederman NG, editors. Handbook of research on science education. Mahwah, NJ, United States: Lawrence Erlbaum Associates; 2007. p. 729_ 80.

27. Roberts D.A. Scientific literacy/science literacy. In: Handbook of research on science education. Mahwah, NJ: Lawrence Erlbaum Associates; 2007. p. 729-80. 